\title{
THE MUTE
}

IMMORTALS SPEAK 
A volume in the series

MYTH AND POETICS

edited by Gregory NagY

A list of titles appears at the end of the book. 


\section{THE MUTE IMMORTALS SPEAK Pre-Islamic Poetry and the Poetics of Ritual}

\section{Suzanne Pinckney Stetrevych}

\section{CORNELL UNIVERSITY PRESS}


Copyright (C) 1993 by Cornell University

All rights reserved. Except for brief quotations in a review, this book, or parts thereof, must not be reproduced in any form without permission in writing from the publisher. For information, address Cornell University Press, Sage House, 512 East State Street, Ithaca, New York 14850.

First published 1993 by Cornell University Press.

First printing, Cornell Paperbacks, 2010

International Standard Book Number 978-0-8014-8046-1

Library of Congress Catalog Card Number 93-I8I73

Printed in the United States of America

Librarians: Library of Congress cataloging information appears on the last page of the book.

$@$ The paper in this book meets the minimum requirements of the American National Standard for Information Sciences-Permanence of Paper for Printed Library Materials, ANSI Z39.48-1984. 
To Julian, Qays, and Khalid 
